\title{
TUNCER CÜCENOĞLU'NUN KÖRDÖVÜŞÜ ADLI OYUNUNDA GECEKONDU VE VAROŞ KÜLTÜRLERININ YANSIMALARI
}

\author{
Tuğçe Mine Aktulay Çakır ${ }^{1}$
}

öz

1950'li yıllarla birlikte Türkiye'de sanayileşmenin başlamasıyla, kent hayatında iş gücüne talep duyulmaya başlamış ve bu da beraberinde kırsaldan kente doğru yoğun bir göçe neden olmuştur. Ancak bu durum kentlerde, konut sıkıntısını, nitelik kaybına uğrayan kent imajını ve işsizliği ortaya çıkarmıştır. Bu süreçte göç alan bölgelerde ortaya yeni kültürler çıkmış (gecekondu, varoş) ve bu kültürler zamanla Türk Tiyatrosu'nu da etkilemiştir. Bu süreç pek çok yazara ilham vermiş, birçok oyun yazılmış, bölge halkının içinde bulunduğu ve yaşadığı sosyal çevre tiyatro oyunlarıyla gözler önüne serilmiştir. Bu yazıda, sanayileşme süreciyle kentlerde başlayan gecekondu ve varoş kültürlerinin Türk tiyatrosu üzerindeki etkileri, Tuncer Cücenoğlu'nun “Kördövüşü” adlı oyunu üzerinde kaynak taraması ve metin çözümlemesi yöntemi kullanılarak anlatılacaktır.

Anahtar Kelimeler: göç, gecekondu, varoş, kördövüşü.

\section{SLUMS AND SLUM CULTURE IN THE GAME NAMED TUNCER CUCENOG- LU KORDOVUS OF REFLECTIONS}

\begin{abstract}
Together with the 1950s, with the start of industrialization in Turkey, the labour force demand in the life of the city began to be heard, and this has caused high levels of immigration to the city from the countryside. However, this situation in the cities, the lack of housing, and unemployment has revealed the image of the city, which suffered a loss of quality. In this process, in the area of immigration new cultures out (slum, ghetto), and over time these cultures influenced the Turkish Theater. This process has inspired many writers, many plays written, resides in the people of the region and the social environment, as well plays have been revealed. In this article, it will be described using the method of discourse analysis begins with the process of industrialization in urban slums and suburbs of the impact on the culture of Turkish theater through the game 's Kördövüş of Tuncer Cücenoğlu.
\end{abstract}

Key Words: migration, slums, suburbs, kördövüşü. 


\section{BUJSS}

9/1 (2016), 187-201

\section{GİRiş}

İkinci Dünya Savaşı'nın bitmesiyle Türkiye yeni bir toplumsal oluşumla karşılaşmış, bu oluşumun getirisi de "hızlı iç göç" olmuştur. Göç, insanlık tarihinin başlamasıyla birlikte günümüze kadar sürmüş ve hâlâ devam etmekte olan bir kavram olduğundan pek çok tanımıyla karşılaşmak mümkündür. Her şeyden önce göç bir “yer değiştirme" hareketidir ve Özer'e göre (2004:11) toplum yapısını değiştiren coğrafi mekân değiştirme sürecinin ekonomik, kültürel, siyasi ve sosyal yönü olan bir harekettir. Göç, sosyoekonomik yapıdan bağımsız olarak ortaya çıkmaz çünkü ekonominin yapısal değişimlerinin en iyi göstergelerin biridir (Üner, 1974:9). Göçler, ekonomik firsatlardan yararlanma isteğinden ötürü olabileceği gibi çevresel faktörlerden ya da savaş, terör gibi birtakım zorunlu sosyal nedenlerden ötürü de olabilir. Göç, sadece Türkiye'de değil, bugün hâlâ pek çok ülkede sorun olmaya devam etmektedir. Öyle ki göç edilen yerlerde konut, ulaşım, içme suyu, hastane gibi altyapı ihtiyaçlarına daha fazla gereksinim duyulmaktadır.

Türkiye'de sanayileşmenin ve kentleşmenin etkisiyle başlayan göç, 1950'li y1llara denk gelmektedir. Bu yıllarda göç, köyden kente doğru seyretmiş, 1980’li yıllardan itibaren daha çok kentten kente doğru bir eğilim göstermiştir (Koçak, 2012: 166). Türkiye'deki iç göç hareketi sadece sanayileşmeyle değil aynı zamanda itici ve çekici nedenlerden kaynaklanan bir nüfus harekedir. Dolayısıyla köylerdeki kırsal alanların ivme kazanması "iticiliği”; kentsel alanlardaki dönüşümün belirleyiciliği de iç göçün “çekiciliği” ile açıklanabilir. Akgür, (1997: 62) itici nedenleri 3 grupta toplar:

-Yaşadığı ortamdan hoşnut olmamak,

•Göç edenlerin etmeyenlere oranla refah ve gelir düzeylerini daha farklı olduklarının görülmesi,

• Çocuklarına, gelecek kuşaklara daha iyi bir hayat sağlama isteği.

Ancak tüm bu itici nedenlere yukarıda bahsedildiği gibi sanayileşmeyi, tarımda makineleşmeyi, doğal afetleri, terör sorunlarını ve kan davaları gibi olayları da eklemek mümkündür. Çekici nedenleri de Sezal, (1992:36), şehrin cazibesi, yüksek yaşam standardı, iş bulma ümidi, ulaşım imkânı ve daha iyi sağlık ve eğitim hizmetlerinden yararlanma olarak belirtmektedir. Çekici nedenleri sosyo-kültürel açıdan el aldığımızda özellikle 1950'li y1llarla birlikte kentlere ne ölçüde yatırım yapıldıysa köylerin de bir o kadar yoksun bırakıldığı gözlemlenmiştir (Öz, 1978: 26).

Göç uzun ya da kısa vadede beraberinde pek çok sorunu da getirmektedir. Aşırı kentleşmeden doğa sıkıntılar, kentlileşememek (uyum süreci) de kent sosyolojisinin önemli konularını oluşturmaktadır (Tekeli, 2008: 180-181). Tüm bunlarla birlikte iç göçlerle Türkçe 'ye de yeni bir kavram olan "gecekondu" kelimesi dâhil olmuştur. Gecekondu kavramı Türk Dil Kurumunca şöyle tanımlanmaktadır: 


\section{BUJSS}

9/1 (2016), 187-201

1. (isim) İmar ve yapı kanunlarına aykırı olarak başkalarına veya kamuya ait arazi veya arsalar üzerinde toprak sahibinin bilgisi ve rızası olmaksızın acele yapılmış konut, kondu.

2. Acele ile yapılıvermiş, derme çatma yapı. Erişim tarihi, 14.03.2016, (http://www.tdk.gov.tr/index.php?option=com_gts\&arama=gts\&guid=TDK.GTS.56e652d87feed5.08186953)

Gecekondu, düşük gelirli istihdam alanlarında çalışan ve sosyokültürel açıdan pek çok farklılıktan dolayı kente uyum sağlamakta zorluk yaşayan nüfusun, başkalarına ait topraklar üzerine yasal olmayan yollarla yapılmış konutların ortaya çıkmasıyla oluşan bir olgudur (Tekşen: 2003: 45). "Gecekondulu" ise, bu konut çevresinde yaşayan kişi ya da aile olarak tanımlanmaktadır. Erişim tarihi, 14.03. 2016,

( h t t p :// w w w.tdk.gov.tr/index.php? option=com_bts \& a r a ma $=$ ke lime\&guid=TDK.GTS.56e656d4be53f2.86930430)

Yaşanan bu olayın tanımlanmasında da yeni bir kavram ortaya çıkmıştır: "Varoş" ve "varoşlu". "Varoşlu" sözcügü giderek günlük yaşamda ve özellikle basında, yaygın olarak kullanılan bir kavram haline gelmiştir. “Varoş” Türk Dil Kurumu tarafından, 'kent veya kasabada kenar mahalle’ olarak tanımlanmıştır. Erman'a (2001:997) göre varoş, 'şiddet', 'sosyal güvensizlik', ‘siyasal radikalizm', ‘sosyal çatışma' ve 'kültürel olarak alt tabakada görülenlerin' oluşturduğu alanlar olarak ifade edilmektedir. Etöz ise, (2000) varoşu şiddetin kol gezdiği, yasa dışı faaliyetlerin hâkim olduğu, toplumla bütünleşmek yerine topluma ve sisteme karşı bir duruşun üretildiği yerler olarak belirtmiştir.

"Varoş" Macarca asıllı bir sözcüktür ve Meydan Larousse'de şehir surlarının dışındaki mahalleler, çevre mahalleler olarak tanımlanmakta, genelde şehrin dış semtleri için kullanılmaktadır. Türkiye bağlamında ise varoş sözcüğünün yaygın olarak kullanılmaya başlanması, 1 Mayıs 1996 olaylarının basında ifade edilmesi sırasında olmuş; örneğin "Varoşlar Kente İndi" "Patlayan Varoşlar” gibi başlıklar atılmış, "kırlardan kentlerin kenarlarına akan milyonlarca insanın, nasıl radikal dinciliğin, terörün ya da Vandalizm'in kucağına itildiğini görmek" gereğinden bahsedilmiştir (Bila 1996'dan akt. Erman, T. 2004,s.12)

1950-1960 yılları arasındaki ekonomik, siyasal, toplumsal değişimler Türk Tiyatrosu'na da yansımıştır. Bu dönemin tiyatro eserlerinde toplum sorunlarına doğru bir yöneliş görülür. Sonuç olarak yaşanan bu toplumsal süreç sonrasında "gecekondu”, "gecekondulu” gibi kavramların yerini giderek "varoş” kavramının aldığını söylemek mümkün olmaktadır. Ancak altını çizmek gerekir ki bu dışlanma akademisyen çevrelerden ziyade basın tarafından uygulanan bir dışlanma olarak gözlemlenmiştir.

\section{•Gecekondu ve Varoş Kültürlerinin Ortaya Çıkış Süreçleri ve İlk Yapılaşmalar:}

1950'li yıllardan itibaren kırsaldan kente kitlesel bir göç olgusuyla tanışan Türkiye'de, bu sarsıcı toplumsal değişimle baş edebilmeyi sağlayacak en temel kurum "gecekondu" olmuştur ve "gecekondulaşma" 


\section{BUJSS}

9/1 (2016), 187-201

bu tarihlerde kurumsallaşmıştır. Devletin 1966 yılında çıkardığg 775 Sayılı Gecekondu Yasası da gecekondulaşmanın önüne geçememiştir. Çünkü sık sık çıkarılan gecekondu afları ile yasal güvence altına alınan gecekondular insanları barınmak için değil, artık gecekonduyu kiralamak ve satmak için yapmaya teşvik etmiştir. Bu da beraberinde gecekondu ticaretini getirmiştir (Serter,1994:95). Bugün gecekondulaşma, barınmanın ötesine geçmiş artık bir rant aracı haline de gelmiştir (Öztürk ve Altuntepe, 2011: 1601). İstanbul'un dışarı doğru genişlemesi ve büyümesi rantı arttırırken, bu artış köy ile kent arasındaki gelir farklılıklarını ortaya çıkarmış ve İstanbul yeni bir cazibe merkezi haline gelmiştir. Eskiden kentin dışında kalan gecekondu alanları bugün kentin ortasında kalmaya başlamıştır.

Tablo 1: Türkiye'de Gecekondu ve Gecekondulu Nüfus

\begin{tabular}{|l|l|l|l|}
\hline Yıllar! & Gecekondu! & $\begin{array}{l}\text { Gecekondulu } \\
\text { Nüfus! }\end{array}$ & $\begin{array}{l}\text { Kentsel Nüfustaki } \\
\text { Payı (\%)! }\end{array}$ \\
\hline $1955 !$ & $50.000 !$ & $250.000 !$ & $\% 4.7 !$ \\
\hline $1960 !$ & $240.000 !$ & $1.200 .000 !$ & $\% 16.4 !$ \\
\hline $1965 !$ & $430.000 !$ & $2.150 .000 !$ & $\% 22.9 !$ \\
\hline $1970 !$ & $600.000 !$ & $3.000 .000 !$ & $\% 23.6 !$ \\
\hline $1980 !$ & $1.150 .000 !$ & $5.750 .000 !$ & $\% 26.1 !$ \\
\hline $1990 !$ & $1.750 .000 !$ & $8.750 .000 !$ & $\% 33,9 !$ \\
\hline $1995 !$ & $2.000 .000 !$ & $10.000 .000 !$ & $\% 35,0 !$ \\
\hline $2002 !$ & $2.200 .000 !$ & $11.000 .000 !$ & $\% 27,0 !$ \\
\hline $2011 !$ & $4.000 .000 !$ & $20.000 .000 !$ & $\% 40.0 !$ \\
\hline
\end{tabular}

Kaynak: Keleş, R. (2004). Kentleşme Politikası. Ankara: İmge Yayınevi, s.561

Tablo 1 incelendiğinde, 1955 yılında sayıları 50.000 olan gecekonduların, 2011 yılına geldiğimizde 4.000.000'a ulaştığını görmekteyiz. Bu da gecekondulaşmanın nasıl bir artış gösterdiğini gözler önüne sermektedir.

Köyden kente göç edenlerin kentle bir bütünleşme sorunu yaşadığı görülmektedir. Bu durum da beraberinde şehirlerde iki ayrı kesimin oluşmasına neden olmuştur (köylüler-şehirliler). Bununla birlikte göç edenler ekonomik açıdan da büyük sıkıntılar yaşamakta, ayrıca şehirlilerin dışlayıcı tutum ve davranışlarına da maruz kalarak kent yaşamına ayak uyduramamaktadırlar (Özer, 2004: 70). Araştırmada söz konusu tiyatro oyununda yazar, gecekondulunun sorunlarına, gecekondu ticaretine ve bundan rant sağlayanlara değinmiş, günümüzde geçerliliğini koruyan toplumsal sorunlara ışık tutmaya çalışmıştır.

\section{-OYUNUN YAPISAL UNSURLARI}

\section{Oyunun Konusu:}

Cumhuriyet Dönemi sonrası Türk Tiyatrosu oyun yazarlarından olan Tuncer Cücenoğlu oyunlarının konularını çoğunlukla, ekonomik, siyasal ve kültürel olaylar oluşturur. 


\section{BUJSS}

9/1 (2016), 187-201

Cücenoğlu, güncel sorunları dile getirdiği ilk oyunu olan Kördövüşü 'nü 1972 yılında yazmıştır. Yazar

"Kördövüşü” adlı oyununda gecekonduda yaşayan insanların dramını ele alır. Oyundaki çekirdek aile yaşadığı tüm olumsuzluklara, çaresizliklere rağmen yapısını korur gibi gözükse de oyunun sonunda aile büyük bir çöküş içine girer. Türk Genel Kültür Sözlüğü “kördövüşü’nü aynı şeyi gerçekleştirecek kişilerin birbirinden habersiz ve birbirlerini engelleyecek biçimdeki düzensiz çabaları olarak tanımlar (www.tgku.com). Bu oyunda da aile bireylerinin hayata tutunma çabaları kördövüşüne karşılık gelmektedir. Kördövüşü, köyden kente göç olgusunu en iyi şekilde yansıtan oyunlardan biridir. 1930'lu-40'lı yıllardan itibaren Anadolu'dan göç eden insanlar, bu toplumsal sürece ortak olmuş, büyük şehirlerde insanların yaşadığı hayat, Anadolu insanına oldukça cazip gelmeye başlamıştır. Köylerdeki hastane, okul, ulaşım gibi eksiklikler, büyük şehrin cazibesi artık Anadolu insanının canına tak ettirmiştir. Daha iyi hayatlar yaşamayı istemek onların da hakkıdır...

Cemal ve ailesi de bu sebeplerden ötürü büyük şehre göç ederler. Başlangıçta her şey bir rüyadan ibarettir. Cemal iyi bir iş bulacak, çocukları okuyup adam olacak, güzel bir evde oturup iyi bir yaşam süreceklerdi. Ama işin bir de tecrübesizlik boyutu vardı. Zamanla işlerin o kadar kolay olmadığı anlaşılır. Gerçekleşeceğine dair güçlü bir inanç beslenen 'Büyükşehir Rüya'sının sona ermesi, beraberinde hüznü ve acıyı getirir. Ankara'daki bir gecekondu mahallesine yerleşmek zorunda olan Cemal ve ailesi oturdukları gecekondunun kirasını bile ödeyememektedir. Zaten o gecekonduyu da zar zor bulmuşlar, ev sahibini ikna edebilmek için epey çaba sarf etmişlerdir. Ailede sadece Cemal çalışmakta ve ailesinin geçimini zor sağlamaktadır. Yatalak bir babaanne, hasta bir kız, bir anne, alkolik, çalışmayan ve karısına şiddet uygulayan bir erkek çocuk ve sürekli iş arayan ve en sonunda yine başka bir büyük şehre göç etmeye mecbur kalan evin küçük oğlu. Hayaller ve ümitlerle başlayan göç yolculuğu bir dramla son bulur. Ama bunun en büyük nedenlerinin altında Cemal ve ailesinin eğitimsizliği, cehaleti yatmaktadır. Devlet, bu toplumsal değişimin beraberinde getirdiği sorunları önleyememiş, geçici çözümler yetersiz kalmıştır. Cemal ve Cemal gibiler bu kültürlerin birer yaratıcısı, temsilcileri ve ülkemizin bir gerçeği haline gelmişlerdir.

\section{Oyundaki Çatışma Alanı:}

Oyunun temel çatışma alanı kurguya dayalı metnin içerisinde yazarın ustaca yerleştirdiği karakterlerin sosyo-kültürel ve sosyo-ekonomik bağlamda ele alınması ve oyun zeminine ustaca oturtulması olarak görülmektedir. Temelde var olan en büyük sorun göç ve göçün beraberinde getirdikleridir. Bu da oyunda sorunlarla baş etmeye çalışan ve en nihayetinde "kördövüşü" haline gelen ve bir nevi yerinde saymaya mahkûm olmayla özdeşleştirilmiş gibidir.

KOCAKARI : (Gözlerini yukarıya kaldırır) Ne istedik Rabbim senden?.. Yanmayacak kadar sıcak, (Cücenoğlu, 2007:173) 


\section{BUJSS}

9/1 (2016), 187-201

donmayacak kadar soğuk istemedik mi? (Daha sert.) Yanmayacak kadar sıcak, donmayacak kadar soğuk!. Yanmayacak kadar sıcak, donmayacak kadar!..

(Artık sesi duyulmaz olur.)

\section{Oyundaki Dil ve Anlatım:}

Tuncer Cücenoğlu'nun bu oyununda dikkati çeken en önemli özellik oyunun dili ve yazarın ustaca anlatımıdır. Yazarın gecekondu yaşantısını bu denli gerçekçi aktarmasındaki başarının altında oyunda kullandığı dilin konuşma diline bu denli yakın olmasıdır. Böylece anlatılmak istenilenler seyirci tarafından kolay anlaşılmaktadır. Oyunda zaman zaman yer alan küfür ve argoların da yazar tarafından oyunun içerisine ustaca yerleştirildiği görülmektedir.

HAMIT : (Sesi oldukça yakından...) Nerdesin ulan? Nereye kaçtın? Çıksana dışarıya!. Yalnız bulduğunda mı erkekliğin tutuyor? Hadi şimdi çıksana!. Hıyar oğlu hıyar!. (İPSİZ birkaç kez davranmak ister... Birakmazlar. ..)

RÜSTEM : (Sesi yakından) Bırak Hamit abi!. Karısının eteğinin altına saklanmıştır!. Çıksana lan hiyar!.

HAMIT: Sabah ne çok erkektin öyle! Şimdi de yapsana erkekliğini ulan!. Çıksana dışarıya!. Çıksana, çıksana!. (Dışarıdan kapıya vurmaya başlarlar...)

(Cücenoğlu, 2007:172)

Cücenoğlu'nun seyirciye kolayca ulaşma amaciyla oluşturduğu bu çeşit bir dil bizlere aynı zamanda oyundaki karakterlerin sosyal konumları, eğitim düzeyleri hakkında da doğrudan bilgi sunar.

\section{-Oyundaki Karakterlerin Analizleri, Ortaya Çıkan Sosyolojik Sonuçların Karakterler}

\section{Üzerinde Yarattığı Etkiler}

\section{Cemal}

55 yaşlarında Devlet Demir Yolları'nda makinist olarak çalışmaktadır. Yaşadıkları gecekonduda annesi, karısı, gelini, kızı ve iki oğluyla birlikte tek maaşla evin geçimini sağlamaya çalışmaktadır. Cemal, karısına ve çocuklarına karşı iyi davranan bir babadır; özellikle kızı Beyhan'a ayrı bir ilgi göstermektedir. Aslında Beyhan'a hissettikleri belki de bir acıma duygusudur; çünkü Beyhan hastadır. Cemal'in tek isteği emekli olup emekli maaşıyla bir şeyler yapabilmektir. Bu yüzden var gücüyle çalışmaktadır. Cemal, fedakârdır. Geldikleri bu koca şehirde hayallerinin ötesine asla geçemeyeceklerini belki de anlayan tek kişidir Cemal. Bu bağlamda, gerçekçidir.

\section{Sıdıka}

Cemal'in karısı Sıdıka, 50 yaşlarındadır. Sıdıka'nın ömrü kaynanasına bakmakla geçmiştir ve artık 


\section{BUJSS}

9/1 (2016), 187-201

yaşadığı hayattan bunalmıştır. Küçücük bir gecekondunun içinde ev halkına hem analık hem de hizmetçilik yapmaktadir.

Kocası Cemal'le yattıkları yer bir perdeyle ayrılmıştır diğer odalardan. Bu da özel hayatlarını olumsuz şekilde etkilemektedir. Evlatlarına karşı tıpkı Cemal gibi Sıdıka da şefkatlidir. Kendi kaynanasından kaynanalık görür; ama gelinine kaynanalık yapmaz. En küçük oğlu Mahir'e karşı ayrı bir şefkat beslemektedir. Bütün bunlara rağmen en büyük cahilliği, Tahir’i adam olur diyerek işsiz güçsüzken evlendirmesi olmuştur. Bu durumdan en çok ağzı yanan, gelin olmuştur.

CEMAL: Sanki sen hiç hata yapmazsın.

SIDIKA: Ne yapmışım?

CEMAL: Daha ne yapacaksın? İşsiz güçsüz oğlanı sen everdin zorunan. Şu ipsiz Tahir evlendirilir miydi? Elaleme rezil ettin bizi.

SIDIKA: Aklı başına gelir diye düşündüm.

(Cücenoğlu, 2007:120)

\section{Kocakarı}

Cemal'in annesi, 75 yaşındadır ve yatağa mahkûmdur. Kocakarı, oyunun en önemli karakteridir; çünkü oyun onun ve Tahir'in üzerinden ilerlemektedir. Kocakarı oyunda bir "simge"dir. Yatalak olduğu için gün içinde sık sık gelini ya da torunları onu tuvalete taşımaktadır. Bu durum kocakarıyı oldukça üzse de çoğu zaman evin en yaşlısı konumunda olmanın verdiği rahatlıkla bu durumu arada bir kendi menfaatine kullanmaktadır. Bütün gün evde olup biteni Cemal'e karısından önce o yetiştirir, bundan keyif alır. Bu durum Sıdıka’yı çok rahatsız eder. Kocakarı, pintidir. Biriktirmiş olduğu parasını kimseye vermek istemez ve bu paranın kefen parası olduğunu vurgulayarak sürekli duygu sömürüsü yapar. Ancak küçük torunu Mahir'e karşı ayrı bir şefkat besler. Öyle ki kefen parası için biriktirdiğinin bir kısmını en zor anlarda kendi oğluna bile vermezken oyunun sonunda İstanbul'da iş bulduğu için gitmek zorunda kalan Mahir'e verir.

\section{İpsiz Tahir}

Evin en büyük oğludur. Lakabından da anlaşılacağı üzere ipsiz sapsız dolaşmaktır. Ne işi vardır ne iş aramaktadır. Üstelik alkol bağımlısıdır ve karısına şiddet uygulamaktadır. Tek derdi bir minibüs sahibi olmak ve bu yolla ileride köşeyi dönmektir. Bu yolda babasının emekli ikramiyesi Tahir için kaçırılmaz bir fırsattır. Tahir kız kardeşi Beyhan’a karşı son derece kötü bir tutum sergilemekte, kızı sürekli itip kakmaktadır. Bu durumu çoğu zaman Cemal bile engelleyememektedir. Tahir karısını çoğu zaman sadece cinsel bir obje ya da evin hizmetlisi olarak görmektedir. Ona göre kadın yatakta karılık, ev işlerinde hizmetçilik yapmalıdır, yeri geldiğinde egosunun bir göstergesi olan dayağını da ses çıkarmadan yemelidir. 


\section{BUJSS}

9/1 (2016), 187-201

\section{Gelin}

Tahir'in karısı, 20 yaşlarındadır. Genç yaşta Tahir'le evlendirilmiş bir gecekonduya gelin gelmiştir. Ne kadınlığını bilmiştir ne başka bir şeyi... Yokluk, umutsuzluk, şiddet onun başına gelen en kötü şeylerdir. Her gün yeni bir ümitle, Tahir'in iş bulacağıyla güne başlar ama günü Tahir'in dayağıyla sona erer. Hiç sesi çıkmaz, çoğu zaman kocakarıyı tuvalete o taşır. Üstelik oturdukları gecekondunun kirasını da kendi babası öder. Böyle bir sefaletin içinde umutlarla, hayallerle yaşama tutunmuştur.

\section{Beyhan}

Cemal'in kızı, 18 yaşlarındadır. Evin en küçük ve en sessiz bireyidir. Beyhan, sık sık oturduğu yerden dalıp dalıp gider. Bu yüzden de abisinden sürekli dayak yer. Kimse onun hasta olduğunun ve bir doktora görünmesi gerektiğini düşünmez. Ailenin cehaleti oyunun sonunda Beyhan'ın bir sara krizine yakalanıp oturduğu yerden yere düşmesiyle sonlanır. Eve doktor yerine getirilen Hazret denilen din istismarcısı elbette ki kızın hastalığına hiçbir çare bulamaz. Cemal, Beyhan'ın evlenip koca evine gitmesini istemektedir; çünkü koca dayağı ağabey dayağından yeğ tutulmaktadır.

\section{Mahir}

Evin küçük oğlu, 23 yaşlarındadır. Ev içindeki en bilinçli kişilerden birisidir. Ne de olsa mektep bitirmiştir; lise mezunudur ve hayata diğerlerinin baktı̆̆ı pencereden bakmamaktadır. Aslında onun da düşüncesi tıpkı başlangıçta babasının yaptı̆̆ı gibi daha büyük bir kente göç edip orada daha iyi bir yaşam sürmektir.

\section{Hazret}

Nefesinin güçlü olduğuna inanılan hoca, 40 yaşlarındadır. Din istismarcısı. Dini kullanarak para karşılı̆̆ında hasta insanları tedavi etmektedir (sözde). Beyhan'ı tedavi etmeye lüks bir otomobille gelir.

HAZRET: Amiin. Amiiiin. (Diğerlerine) Hep birlikte, aynı iğmanla... Amiiin.

BİRLIKKTE: Amiiiin. Amiiin, Amiiin.

HAZRET: (Cebinden küçük bir muska çıkarır) Gel bakayım kızım. Korkma korkma. (Sırtına iğneler. Yeniden dua okur) Amiiin...

BİRLİKTE: (İyice girmişlerdir havaya) Aminiin. Amiin..

HAZRET: Tamam benim işim bitti. Bundan sonrası Allah'a kaldı. Geçmiş olsun kızım.

CEMAL: (Kizara bozara) Ne kadar?

HAZRET: Hakkı Ustanın tanıdığısınız. Münasip bişey verin işte.

CEMAL: (Daha önceden hazırlamış olduğu zarfi içinden çıkararak uzatır) Layık değil ama.. 
HAZRET: (paraları göz ucuyla sayar) Arabayla geldim! Benzini çok yakışır. Ama gene de Hakkı Ustanın hatırı var. Haydi cümleten allahaısmarladık.

(Cücenoğlu, 2007:148)

\section{Hamit}

Gecekondunun sahibi, 40 yaşlarındadır. O da tıpkı Cemal ve ailesi gibi göç ederek gelmiştir Ankara’ya. Ancak diğerlerinden erken davranıp birçok araziyi tapusuz parsellemiştir. Gecekondu ticareti yapıp buradan rant elde edenlerdendir. Bu yolla geçimini sağlamaktadır. Oyunun en uyanık karakteridir, Menfaatleri doğrultusunda hareket eden çıkarcı biridir.

KOCAKARI: N'oldu Hamit oğlum?

HAMIT: Daha n'olsun? Bir söylenti çıktı. Güya belediye buraları istimlak edecekmiş...

SIDIKA: Buraları mı?

CEMAL: Niye?

HАMіT: Devlete niye olur mu Cemal Efendi? Devletin işi... Yıkacak yıkacak... Atacak atacak... Satacak satacak... Asacak asacak...

KOCAKARI: Bizi de sokağa mı atacak? Nerden buluruz ev?

SIDIKA: Ne zaman?

CEMAL: O kadar yakın mi?

HАMіT: Kendinizi düşünüyorsunuz hemen... Ya bana n'olacak? Verecekler elime üç-beş kuruş yıkacaklar her yanı... Ya ben ne yapar, ne ederim?

KOCAKARI: Bir tek senin evleri mi yıkacaklar Hamit oğlum?

HАMіT: Olur mu yahu? Benim evler dediğin topu topu yedi kondu... En az iki yüz hane yıkılacak... Görmediniz mi ölçüp biçerlerken? Kâmilen mahalle kalkacak ortadan...

(Cücenoğlu, 2007:139)

\section{•Kördövüșü Adlı Oyunda Ailenin Sosyolojik Yapısı ve Genel Özellikler}

\section{•İç İçe Yaşam}

Oyunun genel yapısında "iç içe" bir yaşam görülmektedir. Bu iç içe yaşam beraberinde birçok sorunu da getirmektedir. Evin gelini ve Tahir yeni evli bir çifttir. Evin babası Cemal ve karısı Sıdıka evde başka bir oda olmadığından odalarını onlara verirler. Cemal ve Sıdıka'nın yatak odası ise bir perdeyle diğer odalardan ayrılmıştır. Mahir, sofada yer yatağında yatmaktadır. Evin sağ yanındaki odamsı mekânda da Cemal’in karısı Sıdıka ve Beyhan uyumaktadır. Bu iç içe yaşam aile içindeki bireylerin özel hayatları olmadığının bir göstergesidir. 
KOCAKARI: Hoş geldin Hamit oğlum...

SIDIKA: Hoş geldin...

BEYHAN: Hoş geldin Hamit Amca...

HAMIT: Hoş bulduk... (Gözleriyle evi araştırır.) Maşallah iyi sığışmışsınız.

CEMAL: Ne yapalım?

SIDIKA: Kalabalığız ama...

KOCAKARI: Başka çaremiz var mı?

HАMIT: Şu perde?

CEMAL: Bizim Tahir'i everince... Onlara kendi odamızı verdik...

HAMIT: Bilakis yapmak lazım... Biz kim için çalışıyoruz arkadaş? Bütün analar babalar sizin gibi olmalılar aslında...

CEMAL: Muhakkak...

-Alkol Bağımlılı̆̆

Evin en büyük oğlu Tahir eve sürekli alkollü gelir ve zaman zaman karısına şiddet uygulamaktadır. Tahir aynı zamanda işsizdir. İşsizliğin getirdiği maddi sıkıntı ve stres yüzünden alkole ve şiddete sığınan Tahir, Türk örf ve adetlerine uymamakta, sık sık babasına karşı gelmekte, karısını tartaklamakta, kız kardeşini de dövmektedir. Tahir'in tek derdi kısa yoldan köş̧eyi dönmektir. Emek harcayıp alın teri dökerek para kazanmak Tahir'e göre değildir.

CEMAL : (Işı̆̆ı yakar.) Gene mi ha?

KOCAKARI : (Ansızın gelen ışıklan gözlerini uğuşturarak) Hoş gelmişin Cemal...

CEMAL : (Annesinin elini öperken) Hoş bulduk ana... Bu ne böyle? Tu Allah senin gibi evlâdı...

KOCAKARI: Varma üstüne Cemal... Aklı başında mı ki varırsın üstüne?

CEMAL: Benim aklım pek mi başımda? Gece gündüz demeden şu yaşta uyku durak bilmeden gitmekteyim...

KOCAKARI: Sarhoştan deli bile kaçarmış oğlum...

SIDIKA : (Gözlerini ovuşturarak gelir.) Hoş geldin Cemal...

CEMAL: Hoş bulduk, hoş bulduk... Bu adam daha içiyor mu böyle kendini bilmeden?

SIDIKA: Değme ne yapalım?

CEMAL: Değmesi mi kaldı? İş yok güç yok... Evli barklı bir adam. Durmamacasına içiyor. Bu ne biçim iştir yarabbim? Korkarım bir gün bir arabanın altında kalıp...

SIDIKA: Allah korusun... 
CEMAL: Allah bunun neyini korusun? Bigünden bigüne başı secde gördü mü ki korusun? Her gece zilzurna... Her gece... Patlayacak bi gün bi yerleri...

(Cücenoğlu, 2007:114)

\section{•Aile İçi Şiddet}

Evde Tahir dışında kimse birbirine karşı sevgisiz ve saygısız değildir. Tahir, kız kardeşi Beyhan’ı sürekli itip kakmakta, babasının uyarılarını bile dinlememektedir. Ayrıca karısına karşı da çoğu zaman kaba konuşmaktadır ve Tahir'in dayaklarından nasibini en çok alan da karısıdır.

İPSİZ: Ne dedin lan?

GELIN: Bi şey demedim.

İPSİZ: Dedin dedin. Ne dedin?

GELIN: İçtiğini bilirsin dedim.

İPSİZ: Sana ne ulan? Senden mi alıyorum parasını?

GELIN: Benden almıyormuş.

İPSIZ: Asarım tavana bacaklarından haaa!

GELIN: Asarmış.

İPSİZ: Çivilerim namussuzum!.. İstemiyorsan var git babanım evine!

(Cücenoğlu, 2007, 123)

\section{•Örf, Adet, Gelenek ve Göreneklerin Erozyona Uğraması ve Çekirdek Aile Yapısı}

Köylerini terk edip şehre göç eden birçok ailenin yaşadığı maddi çöküntüyü bu aile de yaşamakta ve yaşam mücadelesi uğruna gelenek ve göreneklerini unutmakta; daha doğrusu yaşatamamaktadırlar. Her ne kadar evin tüm bireyleri evin en büyüğü olan babaanneyi sevseler de ona gereken saygıyı çoğu zaman göstermemektedirler ki Türk örf ve adetlerinde büyüklere saygı son derece önemlidir. Aile sosyal bir yapı olup toplumun temel taşıdır ve varlığını sürdürebilmesi, aile birliğinin sağlıklı bir şekilde oluşumuna ve devamlılığına bağlıdır. Burada önemle üzerinde durulması gereken nokta, aile birliğini oluştururken sağlıklı bir yapı kurulmasına dikkat edilmelidir. Aksi halde gerek ekonomik gerek sosyokültürel farklılıklar ya da ileride bunlara bağlı ortaya çıkabilecek sorunlar aile birliğinin bozulmasına neden olacaktır. Kördövüşü adlı oyunda da tüm bu söylenenlerinin örnekleri görülmektedir. Aile içindeki bireyler sorumluluklarını yerine getirememiş ailenin düzeni bozulmuştur. Bu noktada oyundan örneklendirilebilecek en belirgin husus Tahir'in aile kurabilecek gerekli ortamı oluşturmadan ailesi tarafından evlendirilmesidir. Bu noktada aile de en az Tahir kadar hatalıdır. 


\section{BUJSS}

9/1 (2016), 187-201

\section{-Din İstismarı}

Evin küçük kızı Beyhan sara hastasıdır ve oyunun başından itibaren sık sık dalıp gitmektedir. Ancak Beyhan'ın bu dalıp gitmelerine kimse anlam verememekte; hatta abisi Tahir, Beyhan'ın sevgilisini düşündüğünü sanıp onu sürekli itip kakmaktadır. Beyhan'1 doktora göstermek kimsenin aklına gelmez; çünkü cehalet ve yokluk çareyi doktordan değil; dinden medet ummaya sevk eder bu yüzden de eve doktor yerine eve hoca çağırırlar. Bu da eğitimsizliğin ve çaresizliğin bir göstergesidir. Eve gelen hoca da dini kendi çıkarlarına alet ederek para karşılığı Beyhan’ı tedavi edeceğini söyler ve eder de kendince. Ancak zavallı Beyhan'ın bir hocaya değil bir doktora ihtiyacı vardır ve ne yazık ki bunu kendisi dile getiremeyecek kadar aciz, çaresiz ve cahildir.

HAZRET: Aç bakalım. (İçeriye geçer. Sofraya eğilip iyice araştırır) Cin peri işi değil. İz yok burada. (Diğerleri nasıl da bildi der gibilerden bakarlar birbirlerine)

HAZRET: (Beyhan'a alıcı gözle bakar) Maaşallah, çok da güzelmiş kızımız!... Nazar bu nazar!...

HAZRET: Gar gavış, gadalar savış, atmış yetmiş, çıkmış gitmiş.

Hazara huzura, öküz gelmiş pazara,

Beyhan'a nazar edenin iki gözü bozara!...

(Cücenoğlu, 2007,147).

\section{SONUÇ}

Türk toplumunun yıllardan beri yaşamakta olduğu en büyük sorunlardan biri süregelen göç ve beraberinde getirdiği sorunlardır. Gerek sosyal gerekse ekonomik yönlerden şehirlerle köyler arasındaki uçurum arttıkça, iç göç kaçınılmaz bir hale gelmektedir. Bunun yanı sıra 80'li yıllardan itibaren doğudan batıya doğru kayan terör eylemleriyle kendisini gösteren şiddet, giderek toplumda korku ve ekonomide istikrarsızlığa neden olmuştur. Bu durum ülke içindeki ve dışındaki yatırımcıları korkutmakta, bunun sonuncunda da Doğu ve Güneydoğu bölgelerine gereken yatırımlar yapılamamaktadır. Bu durum köylerin iticiliğini ve güvensizliğini arttırarak göç edenlerin sayısını arttırmakta ve aynı zamanda da şehirde yaşayanlar açısından şehir hayatını toplumsal, ekonomik ve siyasi sorunlarla karşı karşıya bırakmaktadır. Dolayısıyla, sosyal politikalar, eğitim, sağlık, sosyal güvenlik ve dayanışma yeniden düzenlemeli ve bu meseleler, yalnızca yardım dağıtmaya yönelik geçici çözümler olarak görülmemelidir. 


\section{BUJSS}

9/1 (2016), 187-201

Bu doğrultuda Kördövüşü adlı oyunun Türkiye’nin önemli gerçeklerini gözler önüne sermiş olması, Türk Tiyatrosu'nun geçmişe ve geleceğe akılcı bir yaklaşımla 1şık tuttuğunun bir kanıtıdır. Tuncer Cücenoğlu, özellikle bu oyununda gecekondu ve varoş kültürünü tüm gerçekliğiyle anlatmış, Türkiye'nin geçirmekte olduğu bu toplumsal süreçte, oyundaki çekirdek ailenin şehir hayatına nasıl yabancı kaldığını, ne tür olaylar yaşadığını gerçekçi ve samimi bir dille bizlere aktarmıştır.

Sonuç olarak, Türkiye içinde bulunduğu bu süreçte konumu gereği pek çok ekonomik, politik, sosyolojik olaylara maruz kalmış ve kalmaya da devam edecektir. Bu noktada Türk Tiyatrosuna ve Türk yazarlarına düşen görev politik bir duruş sergilemek, tiyatronun politik işlevini unutmamak, yaşadığ ve içinde bulunduğu dönemi yansıtmak, yaşananları akıl süzgecinden objektif bir şekilde geçirerek değerlendirmek ve gelecek nesillere de yine objektif bir şekilde aktarmaktır. 


\section{BUJSS}

9/1 (2016), 187-201

\section{KAYNAKÇA}

Akgür, Z. G. (1997). Türkiye’de Kırsal Kesimden Kente Göç ve Bölgeler Arası Dengesizlik 1970-1993, (Ankara: Kültür Bakanlığı Yayınları) No: 201.

Bozkulak, S., (2003). "Gecekonduların “varoşlaşma” sürecinden Gülsuyu Mahallesi”. Türk Sosyal Bilimler Derneği, 8. Ulusal Sosyal Bilimler Kongresi'nde sunulan bildiri, Ankara, 3-5 Aralık.

Cücenoğlu, T., (2007). Kördövüşü (Mitos Boyut Tiyatro Oyun Dizisi 18 Toplu Oyunları 1).

Erman, T., Eken, A., (2004). 'The "Other of the Other" and "unregulated territories" in the urban periphery: Gecekondu violence in the 2000s with a focus on the Esenler case, İstanbul', Cities, 21 (1), pp.57-68.

Erman, T., (2004).“Gecekondu Çalışmalarında 'Öteki' Olarak Gecekondulu Kurguları”, European Journal of Turkish Studies [Online], 1 | 2004, Online since 04 March 2015, Connection on 04 March 2015.

Etöz, Z. (2000). 'Varoş: bir istila, bir tehdit', Birikim, 132, ss.49-53.

Keleş, R. (2004). Kentleşme Politikası, 8. Baskı, Ankara: İmge Yayınevi.

Koçak, Y., Terzi, E. (2012). “Türkiye'de Göç Olgusu, Göç Edenlerin Kentlere Olan Etkileri ve Çözüm Önerileri”, Kafkas Üniversitesi, İktisadi ve İdari Bilimler Fakültesi Dergisi, Cilt 3, Sayı 3, Y11 2012, s.163-184.

Koral, R. (2011). Türkiye'de 4 Milyon gecekondu var!”, Sabah Gazetesi, İstanbul.

Özer, İ. (2004). Kentleşme, Kentlileşme ve Kentsel Değişme, Bursa: Ekin Kitabevi.

Öztürk, M., Altuntepe, N., (2011). Türkiye'de Kentsel Alanlara Göç Edenlerin Kent Ve Çalışma Hayatına Uyum Durumları: Bir Alan Araştırması, Journal Of Yaşar University 3(11) 1587-1625.

Öz, B. (1978). Türkiye’de Göç Olgusu, Sorunları ve Çözümü, İstanbul: Gençlik Basımevi.

Serter, N. (1994). Türkiye'nin Sosyal Yapısı, İstanbul: Filiz Kitabevi.

Sezal, İ. (1992). Şehirleşme, İstanbul: Ağaç Yayıncılık.

Tekeli, İ. (2008). Göç ve Ötesi, İstanbul: Tarih Vakfı Yurt Yayınları.

Tekşen, Adnan (2003). Kentleşme sürecinde bir tampon mekanizma olarak hemşerilik: Ankara'daki Malatyalılar örneği. T.C. Başbakanlık Devlet Planlama Teşkilatı, Ankara.

Üner, S. (1974). "Kırsal Yapıda Değişme ve Kırdan Kente Göçler”, Türkiye'de Nüfus Sorunu Semineri, Antalya. 


\section{BUJSS}

9/1 (2016), 187-201

\section{Google Arama Motorundan}

Erişim tarihi, 14.03.2016,

(http://www.tdk.gov.tr/index.php?option=com_gts\&ara-

ma=gts\&guid=TDK.GTS.56e652d87feed5.08186953 ulaşım tarihi: 14.03.2016)

Erişim tarihi, 14.03. 2016,

(http://www.tdk.gov.tr/index.php?option=com_bts\&arama=ke-

lime\&guid=TDK.GTS.56e $656 \mathrm{~d} 4 \mathrm{be} 53 \mathrm{f} 2.86930430$ )

www.tgku.com

DIE,(2004),http://www.die.gov.tr/konularr/nufuSayimi.htm. 